ACTA UNIVERSITATIS LODZIENSIS

FOLIA LITTERARIA POLONICA 5(35) 2016

http://dx.doi.org/10.18778/1505-9057.35.03

Maria Załęska*

\title{
Rhetorical Aspects of Popular Science
}

Nie wystarczy mówić do rzeczy.

Trzeba mówić do ludzi.

[It is not enough to talk to the point.

One has to talk to people.]

S.J. Lec

\section{Introduction}

A conversation about the winning presentation in the FameLab competition can servee as a meaningful example of the rhetorical measures used by researchers in order to popularise scientific knowledge in the media and within science festivals:

- You've just won the Polish FameLab. What is this competition about?

- Young scientists speak about a scientific concept in an understandable and attractive way to a "non-scientific audience" for three minutes. You can use small props during the presentation.

- You came onto stage in a bathrobe and...?

- And I asked the men: would you sleep well if I told you that during sleep your testicles shrink?

- And what happened? Was there a gasp of terror in the room?

- More like a giggle. And curiosity. I was mostly talking about hamsters which had been given melatonin... ${ }^{1}$

* Dr hab., e-mail: maria.m.zaleska@gmail.com; University of Warsaw, Faculty of Modern Languages, Department of Italian Studies, ul. Oboźna 8, 00-332 Warszawa.

1 „Zoolożka”, M. Borowska's interview with J. Bagniewska, Gazeta Wyborcza 2014, 28.06, „Wysokie Obcasy” supplement, No. 25 (784), p. 8. 
A scientific concept - a hypothesis concerning the cause and effect relation between the given factors (the cause: the impact of melatonin; effect: the behaviour of the hamsters) - was presented as "sexy knowledge", which stirred the imagination of the broad audience and was remembered thanks to an anecdote. The quoted fragment of the conversation will serve as a reference point in order to compare the rhetorical strategies in scientific and popular science communication.

Since popularisation is a communicational activity in demand, a part of strategy aiming at creation of the "knowledge society", it is worth asking if when talking differently (either scientifically or in a popularising manner) - we still say the same? And if not then... what do we say? Since "[...] rhetoric may be defined as the faculty of observing in any given case the available means of persuasion [...]" (Aristotle, Rhetoric 1355b), what rhetorical resources are employed by scientists in their act of constructing knowledge, and what resources are employed by journalists (and often scientists) in their act of "reconstructing" it?

Although there are many intermediate forms between the two orientative poles - specialised scientific communication and popularisation - because of length limitations, this article focuses only on these two communicative situations in order to emphasise the differences between them. For the methodical comparison of the means of construction of scientific and popular science communications the following concepts will be applied: a model of relations between specialised and non-technical communication; modern approaches to the differences between specialised and non-technical communication, and a comparison of scientific and popular science communication within a framework of three rhetorical categories: dispositio, inventio and elocutio.

\section{From esoteric to exoteric communication}

It was noticed already in ancient times that the audience determines the means of communication. In the context of conveying knowledge (especially in the didactic context) the ancients made a distinction - basing on how Aristotle approached more or less knowledgeable listeners - between "internal" and "external" speech.

The "internal" speech - in the ancient nomenclature called esoteric (Greek: esoterikós) - referred to the way Aristotle taught students with already advanced knowledge, who were able to understand the complex notions discussed during the philosopher's lectures. Such a way of conveying knowledge was also called acroamatic (Greek: akroàmai - 'to listen'): few chosen students were allowed to take part in such a lecture. In general, the concept referred to teaching elite groups 
consisting of selected people with already advanced knowledge of a specific discipline (thus the modern understanding of esotericism as knowledge granted to only a few initiated people). The "internal" speech was applied only in a situation of decreasing asymmetry between the sender's knowledge and the knowledge of the recipient, which was already advanced. The listeners aspired seriously to gain the specialised knowledge and thus to become equal to the master ${ }^{2}$.

This "esoteric" speech is characteristic of scientific articles, in which a specialist addresses other specialists. Experts share enormous knowledge - axioms, presuppositions, argumentation rules referring to a specific field implicit for specialists $^{3}$, terminology - which makes it often hermetic for ordinary people.

The "external" speech - that is the exoteric (Greek: exoterikós) in the ancient nomenclature - referred to conveying knowledge to people who were not specialists, in a popular form, without scientific rigour. At the beginning, this term was used in reference to Aristotle's books which presented knowledge in a simple way (in comparison to the esoteric ones, which required advanced knowledge and were written in a specialised language).

The "external" speech can be thus considered a model which popular and popular science texts follow, as they are addressed to non-specialised readers. Because of just elementary understanding of the subject by the audience, the author of the text cannot assume any shared knowledge of the discussed concept. At the very most, the scholar can refer to common daily experiences in order to explain the presented issue, using non-technical language and eliminating from the text the rules of counter-intuitive reasoning typical for a discipline.

\section{From scientific communication to popularisation}

It takes time, it is difficult, it requires effort. Acquisition of specialised knowledge is often expensive. It requires a lot of time, attention, and intellectual effort put into understanding complicated theories and gaining linguistic competences concerning terminology, and also, later on, into the activity of creating knowledge ${ }^{4}$. Relatively few people are willing to invest so much, especially considering that the more advanced the level of knowledge, the smaller the number of interlocutors.

\footnotetext{
${ }^{2}$ See: the modern-day concept of peers: members of the scientific community, who - because they are equals - assess their own works by means of peer review).

${ }^{3}$ Called the field-dependent rules (see: S. Toulmin, R.D. Rieke, A. Janik, "An Introduction to Reasoning", Macmillan Publishing Company, New York-London 1984, p. 17).

${ }^{4}$ See: M. Gotti, "Specialized discourse: linguistic features and changing conventions", Peter Lang, Bern 2003.
} 
It is instant, it is easy, it is pleasant. The populus "the people" - that is the audience in the broad understanding - prefer popularisation: access to knowledge which reveals less demanding thanks to peculiar "substitutes" like using everyday speech instead of specialised language, using a specific example instead of an abstraction and an everyday experience instead of counter-intuitive reasoning. "Knowledge reconstruction" - informing about new scientific concepts, recounting original ways of thinking - is the work of scientists, journalists, people who write for the media ${ }^{5}$ and translators of scientific texts ${ }^{6}$, but also of amateurs who are especially interested in a particular piece of knowledge. The simpler and more attractive the communication, the bigger the number of recipients?

Contemporary researchers of scientific popularisation ${ }^{8}$ treat it as a form of adaptation of the original to the transformed usage conditions: a change within the communicational situation results in a change in the way one speaks. The original message of a scientific text, constructed along with the conventions of communication between scientists, should be converted in such a way as to be understandable for the non-specialised recipient ${ }^{9}$.

Using the modern terms, there is an intertextual relation between scientific texts, which are the effect of "constructing" knowledge, and popular science texts, which are the effect of "reconstructing" it. From the point of view of Egon Werlich's ${ }^{10}$ text typology the "constructing knowledge" texts count as the argumentative ones. Their fundamental rhetorical aim is docere "teaching", that is, in the scientific communication, informing about a reality and/or its new models. In accordance with the traditional idea (often contested ${ }^{11}$ ), "facts speak

5 See: G. Myers, "Discourse studies of scientific popularization: questioning the boundaries", Discourse Studies 2003, Vol. 5 (2), pp. 265-279.

${ }^{6}$ See: T. Konik, „Przypadki retorycznie istotnych zmian redakcyjnych w tłumaczeniach publicystyki prasowej o tematyce gospodarczej”, in: „Retoryka w komunikacji specjalistycznej”, ed. M. Załęska, Polskie Towarzystwo Retoryczne, Warsaw 2015.

${ }^{7}$ Nevertheless, there are cases of contestation of such simplifications by the recipients, which can be illustrated by means of the readers' animated reaction to the speculations concerning Umberto Eco's famous novel The Name of the Rose being republished in a more approachable version, see: M. Załęska, "La semplicità e la semplificazione: fra l'ideologia e la retorica", Circula: Révue d'idéologies linguistiques 2015, No. 2, pp. 192-211, http://circula.recherche.usherbrooke.ca/2015numero-2-fr/ [access: 3.11.2015].

${ }^{8}$ For example T. Piekot, „Mechanizmy popularyzowania wiedzy naukowej”, in: „O trudnym łatwo: materiały sesji poświęconej popularyzacji nauki”, ed. J. Miodek, M. Zaśko-Zielińska, Wydawnictwo Uniwersytetu Wrocławskiego, Wroclaw 2002, p. 4; A. Starzec, „Przemiany w popularyzacji prasowej”, in: „O trudnym”, op. cit., p. 25; P. Donghi, “Sui generis. Temi e riflessioni sulla comunicazione della scienza”, Gius, Laterza \& Figli, Roma-Bari 2006, p. 56.

${ }^{9}$ M. Załęska, ,Retoryka a wiedza: komunikacja niespecjalistyczna i specjalistyczna”, in: ,Retoryka w komunikacji”, op. cit., p. 53-83.

${ }^{10}$ E. Werlich, „Typologie der Texte. Entwurf eines textlinguistischen Modells zur Grundlegung einer Textgrammatik", Quelle \& Meyer, Heidelberg 1975.

${ }^{11}$ See: for example S. Shapin, "Never Pure. Historical Studies of Science as if It Was Produced 
for themselves" - that is why specifying them in a text should be enough to convince (movere). The aesthetical aim of the text - delectare - in a traditional take is considered the least relevant in the scientific communication (although sometimes it is successfully achieved, for example by Galileo ${ }^{12}$ ).

From the point of view of Werlich's typology "knowledge reconstructing" texts count as so-called expository texts, which are in an intertextual relation to the originals. Ways of conveying knowledge to non-specialists - that is the types of speech used within the "knowledge reconstruction" activity - fall within a conventional, orientative continuum, where specific speech genres can be located: popular texts (e.g. short notes on scientific curiosities), popularising texts (longer texts with occasional references to scientific research; also, for example, experts' blogs or the already mentioned FameLab presentations), and popular science texts (longer texts, which systematically recount research conducted by specialists on a specific subject).

Presenting scientific knowledge to non-specialists - in the press, magazines, at science festivals or by means of appealing forms of utterances like the presentations in the FameLab competition - require different configurations of the rhetorical aims. Press readers or the audience of popular science events seek pleasant experiences due to the reception of the conveyed messages, and the editors, journalists and presenters have to maintain their clients' favour. Hence the most important rhetorical aim is - delectare. The popularising communication must be appealing, easily comprehensible and pleasant. The aesthetics of the message helps the docere aim (i.e., informing about scientific concepts). Since, according to Werlich's typology, popularising texts are expository and not argumentative ones, the movere aim should only support the presentation of the scientist, who, applying scientific means, proves a scientific concept to be correct. Nevertheless, in order to increase the recipients' interest in the subject, the journalists - correspondingly with their own aims - suggest stronger theses than those presented in the original scientific texts (for example in order to make information more sensational).

For a synthetic juxtaposition - inspired by the above quoted text - of the differences between scientific communication and popular one, three rhetorical categories (in an unusual order) will be used: dispositio, inventio and elocutio.

by People with Bodies, Situated in Time, Space, Culture, and Society, and Struggling for Credibility and Authority", The Johns Hopkins University Press, Baltimore 2010.

${ }^{12}$ See: T. Sierotowicz, „Od metodycznej polemiki do polemiki metodologicznej. Impresje z lektury «Wagi probierczej» Galileusza wraz z antologią", Wydawnictwo Diecezji Tarnowskiej Biblos, Tarnów 2008. 


\section{Dispositio}

According to the ancient model of text construction, dispositio, is the second stage of text organisation, after inventio. In the original take, the rhetorical dispositio is treated as the general scheme of an argumentative text (from exordium to peroratio), no matter the differences in speech genres.

In contemporary research, which combines rhetoric, discourse analysis and genre analysis, the rhetorical dispositio is also discussed in reference to the information schemes typical for each genre ${ }^{13}$. According to such an approach, dispositio is also analysed as a peculiar inventive means: the functional elements, constitutive of the text scheme, encourage or even force the author to include such types of information. It may be illustrated by the scheme of the research paper in the hard sciences, called IMRAD (Introduction - Methods - Results - And Discussion $)^{14}$.

The zoologist quoted in the introduction, writing a research paper, would have to present these information categories in IMRAD order. Omitting the "Methods" and "Results" sections would result in disqualification of the article: methodology, the rigour of conducting an experimentation or observation, precise enumeration of the variables taken into consideration, and the achieved results constitute the basis of the scientific reliability. These sections include information which allows other scholars to evaluate the credibility of the research and its theoretical interpretation, as well as potential independent verification by means of the given method. That is why the articles have to be sufficiently long (at least 12 pages) in order to include all the necessary details.

In texts which talk about science in a popular way, it is the shortness that is most important. The mentioned FameLab competition imposes time restrictions of up to 3 minutes (the equivalent of 1.5 pages), forcing the participants to use the rhetorical mechanisms applied in advertising or in film trailers. The preference for brachylogical communication (from Greek brachylogy, literally "a short word") means also abridgement and selection in reference to the message of the original. When selecting information one "economises" mostly on on what is truly essential to the researchers' scientific autonomy and critical attitude, i.e. on information about the theoretical assumptions, methods, and variables. In popularisation, the categories selected from the IMRAD model are

\footnotetext{
${ }^{13}$ See: R.M. Coe, "'An arousing and fulfilment of desires'. The rhetoric of genre in the process era - and beyond", in: "Genre and the new rhetoric", ed. A. Freedman, P. Medway, Taylor and Francis, London 1994, pp. 181-190; M. Załęska, "Retorica della linguistica. Scienza, struttura, scrittura", Peter Lang, Frankfurt am Main etc. 2014.

${ }^{14}$ See: J.M. Swales, "Genre Analysis. English in Academic and Research Settings", Cambridge University Press, Cambridge 1993.
} 
those which refer to what is most visible and spectacular: "Results" and "Discussion". Of course, these messages are highly selective, as they are limited to the most striking results and the most interesting conclusions. In other words, in texts which popularise science no determined pattern (such as IMRAD) is adopted. Instead, a more simplistic scheme - introduction, main body, conclusion - shared by all texts, is followed.

\section{Inventio}

Rhetoric itself is understood by Aristotle in the inventive terms, as the already mentioned faculty of observing in any given case the available means of persuasion. Scientific texts and texts which popularise science are quite different, due to the differences in their respective cognitive aims and audiences.

In scientific texts (the "esoteric" ones according to the ancient nomenclature) this faculty of observing the means of persuasion regards the scientific problem itself. Scientists, as experts in a specific discipline, have a professional motivation to be up-to-date with the scientific literature. The research of other scholars can bring them closer to finding an answer to the fundamental question for science: how is reality? That is why titles of research papers do not have to entice with aesthetics or emotions (the delectare aim), but rather have to clearly inform about the subject of the text (the docere aim). A specialist is likely to be attracted by the values essential in science - meant as disinterested search for knowledge - stated already in the reasons for writing the text (causa scribendi). The given answers remain on the abstract level, without indicating any connection with the readers' lives. It influences the construction of the three components of the rhetorical invention: ethos, pathos and logos.

According to Aristotle, ethos as the credibility of the speaker consists of three elements: phronesis, arethé and eunoia. Phronesis ("common sense") is responsible for the speaker's image as a person competent to indicate measures which serve the aims desired by the recipients and compatible with their values; thanks to arethé ("nobility") the speaker emphasises that he or she truly shares the same values as the audience; eunoia ("goodwill") is implying that the speaker acts in favour of the listeners.

In scientific texts, phronesis manifests through displaying the means - the theoretical and methodological assumptions, a specification of data and methods of their elaboration - likely to help other scholars to achieve the goal pursuited in scientific research, i.e. to establish the reality. It also contributes to the achievement of arethé, since it points to the values, especially epistemic ones (truth, quality of cognition, critical thinking, knowledge verification), which the author of the 
text shares with the readers. In function of these one can establish if the speaker acts in favour of the audience of scientists (eunoia).

Apart from so constructed ethos, another emotional rhetorical component, i.e. pathos, is expected to act in science, paradoxically, by its own concealing. Scientific texts are indeed constructed as impersonal, addressing reason only and eliminating emotions ${ }^{15}$.

From the point of view of logos, the traditional understanding of science is best expressed in Maria Skłodowska-Curie's words: "In science, we must be interested in things, not in persons". The reasoning in scientific texts is expected to be, by definition, "impersonal": it should refer to the relationships between facts, data and variables. According to the "regimens of truth" specific for various disciplines, "the available means of persuasion" consists, among others, in displaying the theoretical and methodological frameworks which give sense to the achieved results (for example, in the above quoted case, the cause and effect theory creates a meaningful relation between the melatonin release and the behavioural models).

Within "exoteric" communication (according to the above presented nomenclature) this faculty of observing in any given case the available means of persuasion applies first of all to convince the audience to read the text. The widely understood "general audience" (although this category requires clarification, impossible here because of the limited space of the article) - that is, press readers, or viewers of the FameLab competition - are not interested professionally in updating their knowledge about the current development of science, nor (as they usually think) have personal interest in following it. Hence, the first rhetorical task of the author is to attract their attention on the scientific issues. That is why achieving the rhetorical aim of delectare is so important from the very beginning, that is, from the very title of the text. Titles are there to attract attention and causa scribendi is to be presented in the most attractive manner. Since atraho etymologically means "to attract", what reveals most engaging for recipients who are not scientists?

Popular science texts do not address specialists in a specific field of knowledge, and thus the author's ethos has to be constructed differently. In popular science texts phronesis is constructed by presenting the scientific knowledge as a means to achieve the aims which are shared by the general audience: a better life, health, wealth, agency, etc. Such an approach to the issue helps the writer to realize the arethé component: the author shows that, even as a scientist, he or she shares the same values as the recipients of the text, e.g. social, hedonistic or pragmatic ones (such as increasing control and agency in order to more efficiently

${ }^{15}$ In order to read about sources of such a view on emotions in the context of cognitive practices see: Ch. Plantin, “Les bonnes raisons des émotions. Principes et méthode pour l'étude du discours émotionné”, Peter Lang, Bern etc. 2008. 
achieve one's own life goals). This influences also the realization of eunoia, the third component of ethos: the speaker is likely, thanks to such an approach, to be perceived as acting in favour of his or her audience.

In order to attract the attention of the non-specialist it is necessary to skilfully use pathos: the topic has to evoke emotions, also in order to increase the informativeness of the text (which is understood along with Robert de Beaugrande and Wolfgang U. Dressler ${ }^{16}$ as the degree of novelty of a piece of information for the recipients). In the quoted example the recipients would never think about the intriguing correlation between sleep and the size of their intimate body parts. The shocking question ("Would you sleep well if I told you that during sleep your testicles shrink?") contributed to making the conveyed knowledge more sensational by slightly alarming the audience, as well as amusing them.

From the logos perspective, as one can see in the quoted example, the basic rhetorical decision of the author of the winning presentation was to attract the recipients' attention on the zoological issues by "translating" them into anthropological terms, in other words - showing the audience how the presented issue may directly refer to their own experience. The anthropocentric approach towards science in the popular science texts makes also apply the argumentation focused on the truth "useful" for people. The arguments, thus, do not only concern the relations between "things" (for example, cause and effect relation), but they also stimulate readers' interest showing them what "business" they have in getting familiar with the subject ("Will this be of any help in my life?").

\section{Elocutio}

In the common sense, elocutio constitutes the most basic - since the most visible - difference between scientific texts and popular science texts. Scientific knowledge entails, among other things, mastering advanced linguistic and discursive competences, a kind of "foreign languages", which express the counterintuitive cognition in various disciplines. Terminology reflects human cognitive activity. Sometimes it preserves traces of theories from different stages of scientific development (for example, the sentence The sun goes up and down is a reference to ancient astronomical concepts). The application of a disciplinespecific terminology is very economical and convenient for the specialists, since they have mastered the whole system of the relevant semantic interrelations. They understand also the so-called constitutive metaphors in their respective fields of

\footnotetext{
${ }^{16}$ R.-A.de Beaugrande, W.U. Dressler, „Wstęp do lingwistyki tekstu”, transl. A. Szwedek, Państwowe Wydawnictwo Naukowe, Warsaw 1990.
} 
study (i.e., the metaphors which conceptualize the fundamental discipline subject; for example, language can be conceptualized as structure, as family or as geological layers).

For non-specialists the reception of such a "foreign language" requires an enormous intellectual effort, often surpassing their abilities. In the above quoted conversation, scientists who popularise science are expected to make their message understandable for ordinary people. They have therefore to translate from their "foreign" into "our" language (both being a mother tongue, shared by the author and the recipients); the way is to find a common linguistic and conceptual denominator for the counterintuitive and everyday cognition. The use of common resources - e.g. words, metaphors or comparisons based on the everyday experience - offers the laymen who follows a brief presentation or reads a short text in the media a rough insight into the discussed scientific concept. It is rather familiarity than knowledge. The realizations of the rhetorical goal of delectare, such as catchy comparisons or anecdotes, are easily remembered by the audience. Therefore, the readers can diffuse the information presented in such a way. Achieving the delectare aim contributes, thus, to the so-called tellability of the message: it may be easily retold in many conversations, which helps knowledge popularization.

\section{Conclusion}

Summing up, a question arises: if we talk differently (either scientifically or in a popularising way) do we still say the same? The analysis shows that the subject remains recognisable ("I was... talking about hamsters which had been given melatonin"); however, the rhetorical choices - realized on the genres level, along with their specific dispositio, as well as on the inventio and elocutio levels - have a deep impact. Every gain (shortness, appealingness, intelligibility for non-specialists) comes with a price. In popular science texts, knowledge is presented not only in different words and in more succint way, but it focuses also on slightly different things. The authors focus on concrete experience relevant for the recipients' lives instead of discussing abstract concepts. They address anthropocentric issues about "people" instead of the issues about "things". They try to develop "interested interest" (by pointing out the practical benefits for the readers of their texts) instead of "disinterested interest" (by just revealing the reality, along with the science standards, without mentioning any profits stemming from this knowledge for readers). Therefore, it turns out that - modifying Stanisław J. Lec's motto of this article - it is not enough to talk about concepts. One has to talk about people. 


\section{Bibliography}

Beaugrande R.-A.de, Dressler W.U., „Wstęp do lingwistyki tekstu”, transl. A. Szwedek, Państwowe Wydawnictwo Naukowe, Warsaw 1990.

Coe R.M., "'An arousing and fulfilment of desires'. The rhetoric of genre in the process era - and beyond", in: "Genre and the new rhetoric", ed. A. Freedman, P. Medway, Taylor and Francis, London 1994, pp. 181-190.

Donghi P., "Sui generis. Temi e riflessioni sulla comunicazione della scienza", Gius, Laterza \& Figli, Roma-Bari 2006.

Gotti M., "Specialized discourse: linguistic features and changing conventions", Peter Lang, Bern 2003.

Konik T., „Przypadki retorycznie istotnych zmian redakcyjnych w tłumaczeniach publicystyki prasowej o tematyce gospodarczej”, in: „Retoryka w komunikacji specjalistycznej”, ed. M. Załęska, Polskie Towarzystwo Retoryczne, Warsaw 2015, pp. 187-216.

Myers G., "Discourse studies of scientific popularization: questioning the boundaries", Discourse Studies 2003, Vol. 5 (2), pp. 265-279.

Piekot T., „Mechanizmy popularyzowania wiedzy naukowej”, in: „O trudnym łatwo: materiały sesji poświęconej popularyzacji nauki”, ed. J. Miodek, M. Zaśko-Zielińska, Wydawnictwo Uniwersytetu Wrocławskiego, Wroclaw 2002, pp. 95-110.

Plantin Ch.,"Les bonnes raisons des émotions. Principes et méthode pour l'étude du discours émotionné”, Peter Lang, Bern etc. 2008.

Shapin S., "Never Pure. Historical Studies of Science as if It Was Produced by People with Bodies, Situated in Time, Space, Culture, and Society, and Struggling for Credibility and Authority", The Johns Hopkins University Press, Baltimore 2010.

Sierotowicz T., „Od metodycznej polemiki do polemiki metodologicznej. Impresje z lektury «Wagi probierczej» Galileusza wraz z antologią", Wydawnictwo Diecezji Tarnowskiej Biblos, Tarnów 2008.

Starzec A., „Przemiany w popularyzacji prasowej”, in: „O trudnym łatwo: materiały sesji poświęconej popularyzacji nauki”, ed. J. Miodek, M. Zaśko-Zielińska, Wydawnictwo Uniwersytetu Wrocławskiego, Wroclaw 2002, pp. 24-31.

Swales J.M., “Genre Analysis. English in Academic and Research Settings”, Cambridge University Press, Cambridge 1993.

Toulmin S., Rieke R.D., Janik A., "An Introduction to Reasoning”, Macmillan Publishing Company, New York-London 1984.

Werlich E., „Typologie der Texte. Entwurf eines textlinguistischen Modells zur Grundlegung einer Textgrammatik", Quelle \& Meyer, Heidelberg 1975.

Załęska M., "La semplicità e la semplificazione: fra l'ideologia e la retorica", Circula: Révue d'idéologies linguistiques 2015, No. 2, pp. 192-211, http://circula.recherche.usherbrooke. ca/2015-numero-2-fr/ [access: 3.11.2015].

Załęska M., "Retorica della linguistica. Scienza, struttura, scrittura", Peter Lang, Frankfurt am Main etc. 2014.

Załęska M., „Retoryka a wiedza: komunikacja niespecjalistyczna i specjalistyczna”, in: „Retoryka w komunikacji specjalistycznej”, ed. M. Załęska, Polskie Towarzystwo Retoryczne, Warsaw 2015, pp. 53-83.

„Zoolożka”, M. Borowska’s interview with J. Bagniewska, Gazeta Wyborcza 2014, 28.06, „Wysokie Obcasy" supplement, No. 25 (784), pp. 8-13. 
Maria Załęska

\section{Rhetorical Aspects of Popular Science}

\section{(Summary)}

After having distinguished the two main contexts for the transmission of knowledge - the esoteric and exoteric - the paper offers a systematic comparison between scientific and popular science texts in terms of inventio, dispositio and elocutio. The popular science texts tend to present knowledge in anthropocentric terms, showing the relevance of the message to the recipients' everyday lives. They turn out to be shorter than genuine scientific texts, and this is achieved, in part, by eliminating information about the methodologies used. The user-friendly vocabulary offers the audience a sense of familiarity with the presented topic, which is, however, different from in-depth specialist knowledge.

Keywords: scientific popularization, rhetoric, inventio, dispositio, elocutio. 